\title{
Thrust and Torque Analysis on Propeller C4-40 with The Addition of Kort Nozzle to Pitch Variation
}

\author{
Irfan Syarief Arief ${ }^{1}$, Achmad Baidowi ${ }^{2}$, Maria Ulfa ${ }^{3}$ \\ (Received: 27 August 2021 / Revised: 06 September 2021 / Accepted: 22 September 2021)
}

\begin{abstract}
CPP propeller (Controllable pitch propeller). The CPP propeller can change pitch angles, and at certain pitches it can pull the ship backwards without having to change the rotation. But keep in mind that the CPP has only one pitch design where changing the pitch position means reducing the efficiency of the propeller. So it takes a kort nozzle to increase efficiency. The addition of a kort nozzle is one of the developments of an Energy Saving Device (ESD) which in addition to increasing efficiency it is also able to increase the thrust. Problem formulation of this research is to find out changes in thrust, torque and efficiency on the propeller CPP C440 after the addition of kort nozzle 37 . This research begins with determining the dimensions of the propeller, also the types and dimensions of the nozzle. Then the design and drawing of the propeller C4-40 with a kort nozzle 37 was carried out for pitch changes of $0^{\circ}, 22.5^{\circ}$ and $45^{\circ}$. The next step is a meshing process where each pitch the number of meshing ranges from 2.3 to 3.5 million cells. The last step is to simulate the performance of the propeller with the nozzle using software based on Computational Fluid Dynamic. From this research, it can be concluded that the addition of kort nozzle 37 on the propeller C4-40 changes the thrust, torque and efficiency values significantly. Thrust only increased at pitch $0^{\circ} \mathrm{J} 1.4$ and pitch $22.5^{\circ}$. The greatest increase in thrust at pitch $22.5^{\circ} \mathrm{J} 0.6$ is $88.74 \%$. Torque is reduced except for pitch $0^{\circ} \mathrm{J} 0.8-1.4$. The biggest decrease in torque at pitch $45^{\circ} \mathrm{J} 1.2$ is $83 \%$. Meanwhile efficiency has decreased at all pitch angles. Where the biggest decrease in pitch $45^{\circ} \mathrm{J} 1$ is $99.83 \%$.
\end{abstract}

Keywords-CFD, CPP, efficiency, kort nozzle, thrust, torque.

\section{INTRODUCTION}

\section{A} this time there are various types of propellers, one of which is the CPP propeller (Controllable pitch propeller). The CPP propeller can change the pitch angle, and at certain pitches it can pull the ship backwards without having to change the rotation. One of the advantages of changing the pitch is that it can regulate the speed of the ship, at a smaller pitch with higher rpm usually for sailing, and a larger pitch by reducing engine speed to accelerate the ship's speed. But keep in mind that the CPP has only one pitch design where changing the pitch position means reducing the efficiency of the propeller. So it takes a kort nozzle to increase efficiency. Tube with $(1 / \mathrm{D} \sim 0.5)$ suitable for low-load propellers, at high load coefficient prices, the propeller efficiency in the nozzle will be up to 0.06 higher than the equivalent propeller efficiency. this means equal to a $15 \%$ increase in force [1].

The addition of a kort nozzle is one of the developments of Energy Saving Device (ESD) which in addition to increasing efficiency, has also been proven to be able to make the speed of a ship more optimal and effective, thus increasing the ship's thrust force up to

Irfan Syarief Arief, Departement of Marine Engineering, Institut Teknologi Sepuluh Nopember, Surabaya 60111, Indonesia, Email: irfansya@its.ac.id

Achmad Baidowi, Departement of Marine Engineering, Institut Teknologi Sepuluh Nopember, Surabaya 60111, Indonesia, Email: ahmadbai@gmail.com

Maria Ulfa, Departement of Marine Engineering, Institut Teknologi Sepuluh Nopember, Surabaya 60111, Indonesia, Email: anggiagustina470@gmail.com several percent. One of the research conducted on the addition of the installation of Energy Saving Devices, namely propeller boss cap fins and kort nozzle on propeller type B series and AU series with the CFD method. The results obtained on the propeller with the addition of a nozzle kort is an increase in thrust of $35.21 \%$ (on the AU propeller) and $10.37 \%$ (on the B Series propeller). This research added that the propeller with the nozzle installation produces a high pressure area behind the blade and a low pressure area in front and this pressure difference increases the propeller thrust [2].

Kort nozzle is a propeller wrapper in the form of a foil-shaped plate [3]. The phenomenon of the propeller enclosed in a tube (kort nozzle) is that the velocity of the air flow inside the tube was faster than the air flow outside the tube, resulting in a lower pressure inside the tube than the pressure outside the tube. This pressure difference results in the emergence of additional thrust (thrust) [4].

Since 1972 systematic experiments with controllable pitch propellers in nozzles have been started. The nozzles used in the experiment were nozzles from the Ka-series, namely nozzles 19A, 22, 24, 37 and nozzles 38 used in the CP-series [5] Elbatran et al (2014) conducted a research on the characteristics of open and ducted CPP using nozzles 19A, 22, 37 and 38. The efficiency of the $\mathrm{CP}$ thruster and $\mathrm{CP}$ thruster nozzle system or effectiveness under static conditions in this study can be derived as a figure of merit (FOM). which is obtained from the zero thrust coefficient to the power of 1.5 divided by to the power of 1.5 times the zero torque coefficient. Where the maximum effectiveness or 
figure of merit obtained in the ahead condition occurs at nozzle 37 , but in the astern condition is the very bad performance and the maximum effectiveness occurs at nozzle 38. In other words, the CP propeller in nozzle 37 is the best performance when used in both conditions. [6] Another study was also conducted by Bhattacharyya et al (2016) about the scale effect of the controllable pitch propeller on the characteristics of open water with nozzle nozzles 19A, 37 and InnoDuct10. The scale effect here uses the pitch setting. Where it is explained in the results of his research that the highest thrust of the scale effect on open water characteristic is obtained at nozzle 37. [7]

Considering the benefits of adding kort nozzle to FPP, the author intends to develop a thrust and torque analysis of one of the CPP propellers, namely the propeller C4-40 with the addition of kort nozzle 37 , especially at different pitch angles.

\section{METHOD}

\section{A. Data Collection}

The main data of Propeller wageningen series C4-40 are as follows:

- Diameter

: $316.6 \mathrm{~mm}$

- Number of blades

$: 4$

- Expanded area ratio

$: 0.4$

$-(\mathrm{P} / \mathrm{D})$

$: 1.4$

- Pitch angles

- Speed

$: 0^{\circ}, 22.5^{\circ}$ and $45^{\circ}$

: 900 RPM

Nozzle ordinate data displays the percentage of the $\mathrm{L}$ or Ld (duct length) value. The Ld value (nozzle length) is obtained from the $L d / D$ value which is varied according to the type of nozzle used. In this paper, nozzle 37 is used so that the $\mathrm{Ld} / \mathrm{D}$ value is 0.5 . [8]

\section{B. Model Drawing}

The modeling was done using the rhinoceros application. . The image is then saved in parasolid form. and running. The meshing process is the process of identifying an object which is defined as small blocks or commonly known as cells.

\section{Validation of Running Results}

Meshing validation can be assessed from the relative error value of the results of variation 1 and variation 2 (e21). [9] The value of e21 can be formulated as follows:

$\mathrm{e}_{21}=\left|\frac{f 2-f 1}{f 1}\right|$

The validation used is meshing validation, where the meshing validation uses a different number of cells.

\section{E. Data Analysis}

Open water characteristics consist of Thrust coefficient (KT), coefficient torque (KQ), and advanced coefficient (J): [3]

$$
\begin{aligned}
& \mathrm{K}_{\mathrm{T}}=\frac{T}{\rho n^{2} D^{4}} \\
& \mathrm{~K}_{\mathrm{Q}}=\frac{Q}{\rho n^{2} D^{5}} \\
& \mathrm{~J}=\frac{V_{I}}{n x D} \\
& \eta_{0}=\frac{K_{Y}}{K_{Q}} \frac{I}{2 \pi}
\end{aligned}
$$

Where :

$$
\begin{array}{ll}
\mathrm{Va} & =\text { advanced speed }(\mathrm{knots}) \\
\mathrm{D} & =\text { propeller diameter }(\mathrm{m}) \\
\mathrm{n} & =\text { propeller rotation }(\mathrm{rps}) \\
\mathrm{T} & =\text { propeller thrust }(\mathrm{N}) \\
\mathrm{Q} & =\text { propeller torque }(\mathrm{Nm}) \\
\rho & =\text { density of fluid (fluid density) }(\mathrm{Kg} / \mathrm{m} 3)
\end{array}
$$

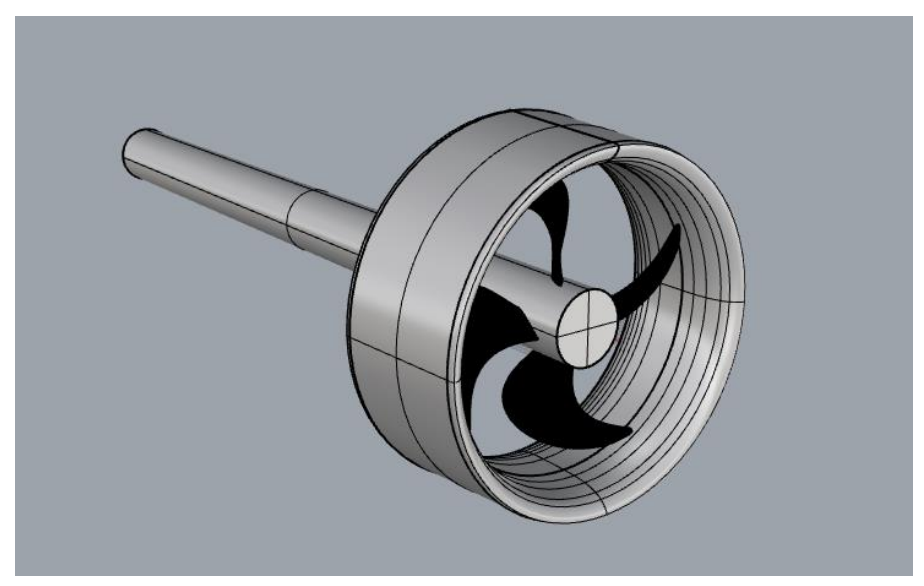

Figure. 1. Propeller C4-40 (pitch $45^{\circ}$ ) with kort nozzle 37.

\section{Open Water Test Simulation}

The simulation is carried out on the Numeca FINEmarine application with 2 steps, namely meshing

\section{RESULTS AND DISCUSSION}

A. Propeller Model 
International Journal of Marine Engineering Innovation and Research, Vol. 6(3), Sept. 2021. 185-194 (pISSN: 2541-5972, eISSN: 2548-1479)

For propeller C4-40 data has been written in point 2.1. The following is a cross-sectional image of the propeller $\mathrm{C} 4-40$ from the side at each pitch angle :

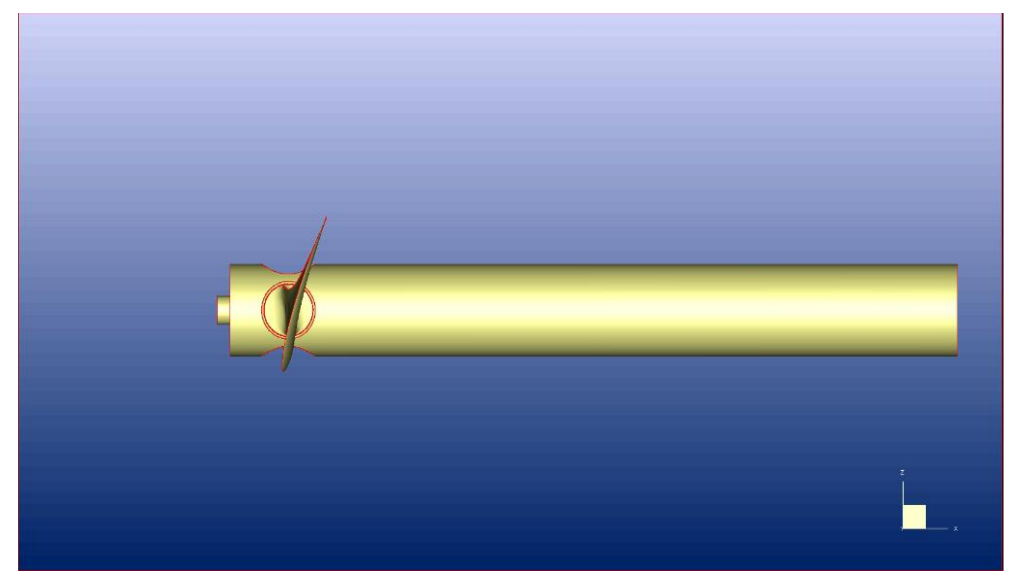

Figure. 2. Propeller $\mathrm{C} 4-40$ pitch angle $0^{\circ}$.

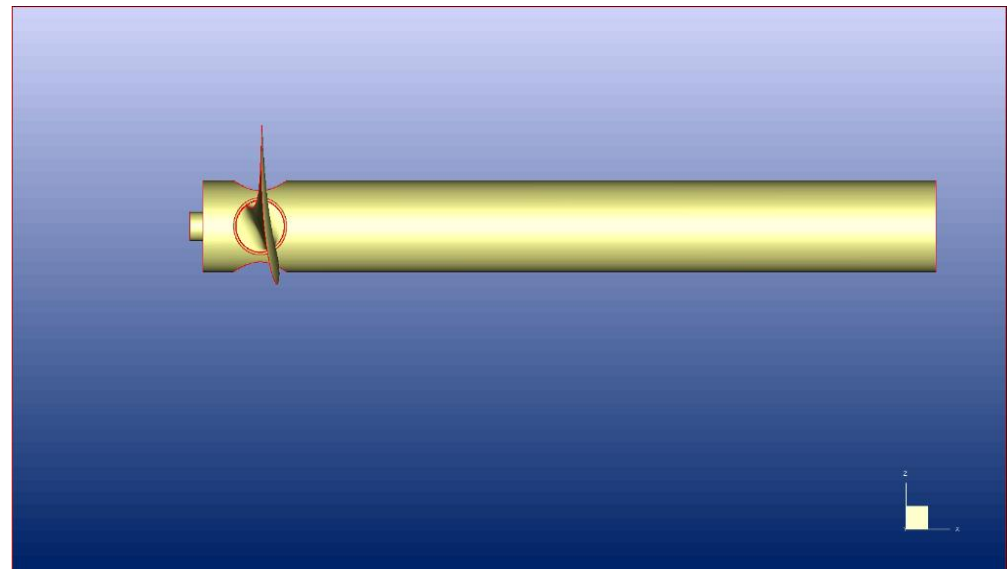

Figure. 3. Propeller $\mathrm{C} 4-40$ pitch angle $22.5^{\circ}$.

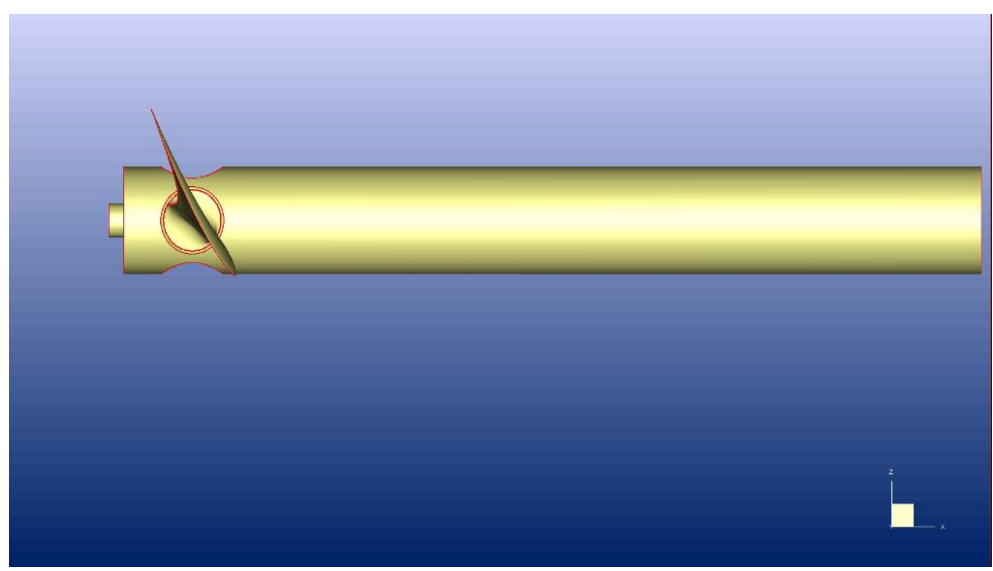

Figure. 4. Propeller C4-40 pitch angle $45^{\circ}$. 
International Journal of Marine Engineering Innovation and Research, Vol. 6(3), Sept. 2021. 185-194 (pISSN: 2541-5972, eISSN: 2548-1479)

B. Propeller Model C4-40 Propeller Characteristics in Open Water Test

TABLE 1.

SIMULATION RESULTS OF PROPELLER C4-40 AT PITCH ANGLE $0^{\circ}$

Simulation Result of Propeller C4-40 at Pitch angle $0^{\circ}$

\begin{tabular}{|c|c|c|c|c|c|c|c|c|c|c|}
\hline RPM & RPS & $\mathrm{Rad} / \mathrm{s}$ & $\mathrm{Va}$ & $\mathrm{J}$ & $\mathrm{T}(\mathrm{N})$ & $\begin{array}{c}\mathrm{Q} \\
(\mathrm{Nm})\end{array}$ & пo & KT & KQ & $10 \mathrm{KQ}$ \\
\hline 900 & 15 & 94.24778 & 2.8494 & 0.6 & -898.584 & 27.714 & 0.981 & 0.388 & 0.038 & 0.378 \\
\hline 900 & 15 & 94.24778 & 3.7992 & 0.8 & $-1,142.342$ & 34.083 & 1.352 & 0.493 & 0.046 & 0.465 \\
\hline 900 & 15 & 94.24778 & 4.749 & 1 & $-1,504.263$ & 41.949 & 1.808 & 0.649 & 0.057 & 0.572 \\
\hline 900 & 15 & 94.24778 & 5.6988 & 1.2 & $-1,947.885$ & 50.223 & 2.346 & 0.841 & 0.068 & 0.685 \\
\hline 900 & 15 & 94.24778 & 6.6486 & 1.4 & $-2,531.807$ & 60.405 & 2.958 & 1.093 & 0.082 & 0.823 \\
\hline
\end{tabular}

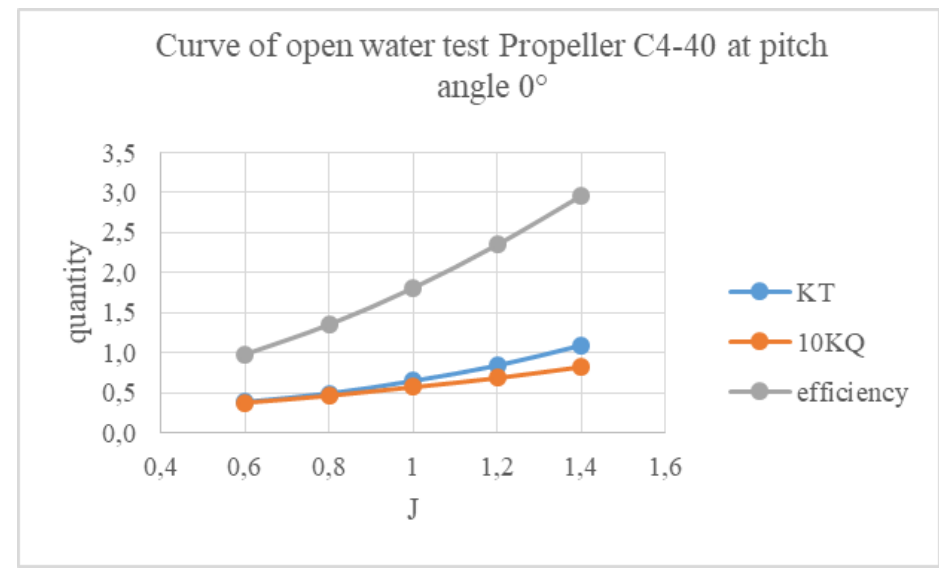

Figure. 5. Characteristics of propeller $\mathrm{C} 4-40$ at pitch angle $0^{\circ}$.

TABLE 2.

SIMULATION RESULTS OF PROPELLER C4-40 AT PITCH ANGLE $22.5^{\circ}$

Simulation Result of Propeller C4-40 at Pitch angle 22.5

\begin{tabular}{|c|c|c|c|c|c|c|c|c|c|c|}
\hline RPM & RPS & $\mathrm{Rad} / \mathrm{s}$ & $\mathrm{Va}$ & $\mathrm{J}$ & $\mathrm{T}(\mathrm{N})$ & $\begin{array}{c}\mathrm{Q} \\
(\mathrm{Nm})\end{array}$ & пo & KT & KQ & $10 \mathrm{KQ}$ \\
\hline 900 & 15 & 94.24778 & 2.8494 & 0.6 & -136.050 & 5.261 & 0.782 & 0.059 & 0.007 & 0.072 \\
\hline 900 & 15 & 94.24778 & 3.7992 & 0.8 & -459.825 & 0.454 & 40.827 & 0.198 & 0.001 & 0.006 \\
\hline 900 & 15 & 94.24778 & 4.749 & 1 & -858.396 & 7.939 & 5.451 & 0.370 & 0.011 & 0.108 \\
\hline 900 & 15 & 94.24778 & 5.6988 & 1.2 & $-1,293.408$ & 16.021 & 4.884 & 0.558 & 0.022 & 0.218 \\
\hline 900 & 15 & 94.24778 & 6.6486 & 1.4 & $-1,810.114$ & 25.286 & 5.053 & 0.781 & 0.034 & 0.345 \\
\hline
\end{tabular}


International Journal of Marine Engineering Innovation and Research, Vol. 6(3), Sept. 2021. 185-194 (pISSN: 2541-5972, eISSN: 2548-1479)

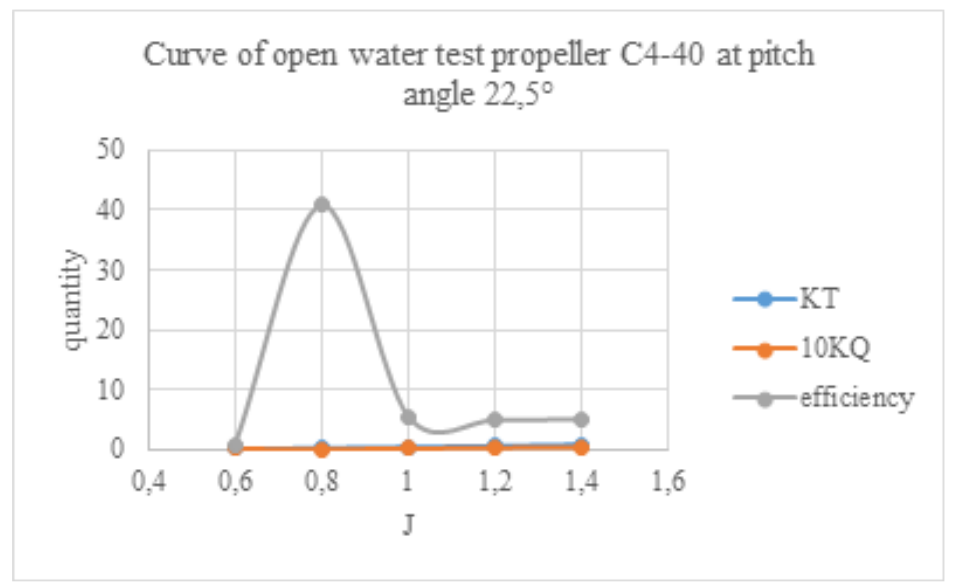

Figure. 6. Characteristics of propeller $\mathrm{C} 4-40$ at pitch angle $22.5^{\circ}$.

TABLE 3.

SIMULATION RESULTS OF PROPELLER C4-40 AT A PITCH ANGLE $45^{\circ}$

Simultion result of propeller $\mathrm{C} 4-40$ at pitch angle $45^{\circ}$

\begin{tabular}{|c|c|c|c|c|c|c|c|c|c|c|}
\hline RPM & RPS & $\mathrm{Rad} / \mathrm{s}$ & $\mathrm{Va}$ & $\mathrm{J}$ & $\mathrm{T}(\mathrm{N})$ & $\begin{array}{c}\mathrm{Q} \\
(\mathrm{Nm})\end{array}$ & no & KT & KQ & $10 \mathrm{KQ}$ \\
\hline 900 & 15 & 94.24778 & 2.8494 & 0.6 & $1,124.559$ & 75.905 & 0.448 & 0.485 & 0.103 & 1.035 \\
\hline 900 & 15 & 94.24778 & 3.7992 & 0.8 & 903.153 & 64.327 & 0.566 & 0.390 & 0.088 & 0.877 \\
\hline 900 & 15 & 94.24778 & 4.749 & 1 & 682.086 & 52.631 & 0.653 & 0.294 & 0.072 & 0.717 \\
\hline 900 & 15 & 94.24778 & 5.6988 & 1.2 & 457.132 & 40.187 & 0.688 & 0.197 & 0.055 & 0.548 \\
\hline 900 & 15 & 94.24778 & 6.6486 & 1.4 & 217.581 & 25.698 & 0.598 & 0.094 & 0.035 & 0.350 \\
\hline
\end{tabular}

Curve of open water test propeller $\mathrm{C} 4-40$ at pitch angle $45^{\circ}$

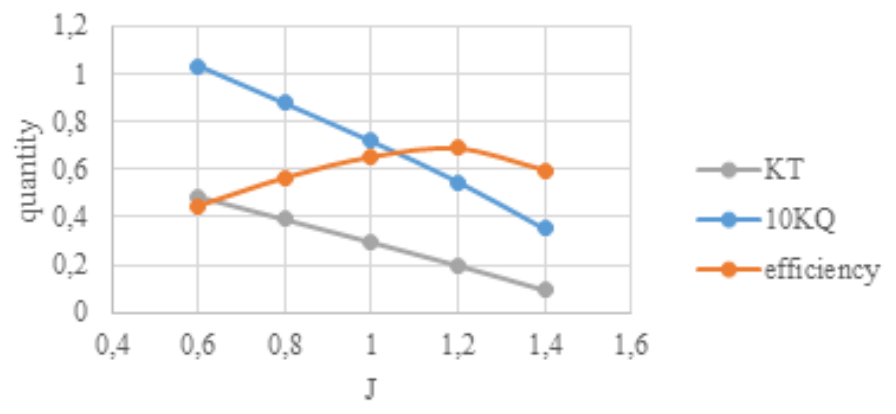

Figure. 7. Characteristics of propeller C4-40 at pitch angle $45^{\circ}$. 
C. Analysis of Open Water Test Propeller C4-40 with the addition of 37 . Kort Nozzle

1) Analysis of Propeller C4-40 Pitch Angle $0^{\circ}$ with Kort Nozzle 37
For the efficiency value produced by the propeller C4-40, the pitch angle $0^{\circ}$ with kort nozzle 37 has decreased compared to without kort nozzle. The highest efficiency decrease was at $\mathrm{J} 0.6$ as much as $38.59 \%$, from efficienc 0.98 to 0.6 .

TABLE 4.

ANALYSIS OF PROPELLER C4-40 PITCH ANGLE $0^{\circ}$ WITH KORT NOZZLE 37

\begin{tabular}{|c|c|c|c|c|c|c|c|c|c|c|c|}
\hline \multirow[b]{2}{*}{$\mathrm{J}$} & \multicolumn{3}{|c|}{$\begin{array}{c}\text { Simulation Result of } \\
\text { Propeller C4-40 at Pitch } \\
\text { Angle } 0^{\circ}\end{array}$} & \multicolumn{5}{|c|}{$\begin{array}{l}\text { Simulation Result of Propeller C4-40 at Pitch } \\
\text { Angle } 0^{\circ}+\text { nozzle } 37\end{array}$} & \multicolumn{3}{|c|}{ increase } \\
\hline & $\mathrm{T}(\mathrm{N})$ & $\begin{array}{c}\mathrm{Q} \\
(\mathrm{Nm}) \\
\end{array}$ & no & $\mathrm{T}(\mathrm{N})$ & $\begin{array}{c}\mathrm{Q} \\
(\mathrm{Nm}) \\
\end{array}$ & no & KT & $10 \mathrm{KQ}$ & $\mathrm{T}(\%)$ & $\mathrm{Q}(\%)$ & no \\
\hline 0.6 & -898.58 & 27.71 & 0.98 & -516.21 & 25.92 & 0.60 & 0.22 & 0.35 & -42.55 & -6.46 & -38.59 \\
\hline 0.8 & $-1,142.34$ & 34.08 & 1.35 & -846.83 & 35.47 & 0.96 & 0.37 & 0.48 & -25.87 & 4.07 & -28.77 \\
\hline 1 & $-1,504.26$ & 41.95 & 1.81 & $-1,224.88$ & 46.68 & 1.32 & 0.53 & 0.64 & -18.57 & 11.28 & -26.82 \\
\hline 1.2 & $-1,947.89$ & 50.22 & 2.35 & $-1,782.08$ & 59.60 & 1.81 & 0.77 & 0.81 & -8.51 & 18.68 & -22.91 \\
\hline 1.4 & $-2,531.81$ & 60.40 & 2.96 & $-2,810.02$ & 80.85 & 2.45 & 1.21 & 1.10 & 10.99 & 33.85 & -17.08 \\
\hline
\end{tabular}

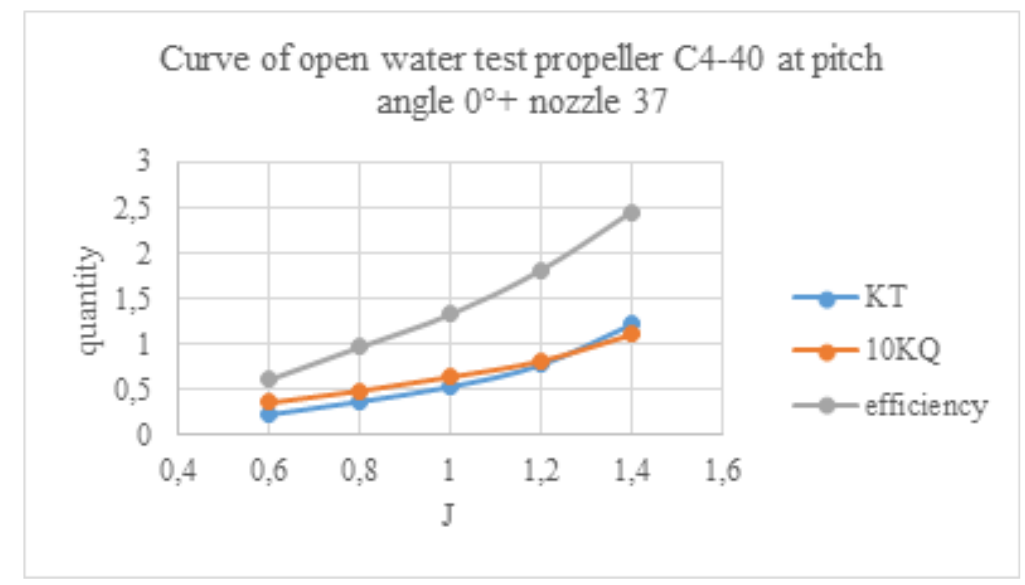

Figure. 8. Curve Open Water Test Propeller C4-40 pitch angle $0^{\circ}$ and nozzle 37.

From table 4 it can be seen that the addition of kort nozzle 37 on the propeller $\mathrm{C} 4-40$ pitch angle $0^{\circ}$, the thrust value decreased except for J 1.4

The torque value increases with each addition of $\mathrm{J}$, only at J 0.6 the torque decreases by $6.46 \%$.
2) Analysis of Propeller C4-40 Pitch Angle $22.5^{\circ}$ with Kort Nozzle 37

From table 5 it can be seen that the addition of kort nozzle 37 on the propeller $\mathrm{C} 4-40$ pitch angle $22.5^{\circ}$ causes the thrust value to increase significantly compared to propeller without nozzle.

TABLE 5.

ANALYSIS OF PROPELLER C4-40 PITCH ANGLE $22.5^{\circ}$ WITH KORT NOZZLE 37

\begin{tabular}{|c|c|c|c|c|c|c|c|c|c|c|c|c|}
\hline \multirow[b]{2}{*}{$\mathrm{J}$} & \multicolumn{3}{|c|}{$\begin{array}{c}\text { Simulation Result of } \\
\text { Propeller C4-40 at Pitch } \\
\text { Angle } 22.5^{\circ}\end{array}$} & \multicolumn{6}{|c|}{$\begin{array}{c}\text { Simulation Result of Propeller C4-40 at Pitch Angle } 22.5^{\circ}+ \\
\text { nozzle } 37\end{array}$} & \multicolumn{3}{|c|}{ increase } \\
\hline & $\mathrm{T}(\mathrm{N})$ & $\begin{array}{c}\mathrm{Q} \\
(\mathrm{Nm})\end{array}$ & no & $\mathrm{T}(\mathrm{N})$ & $\mathrm{Q}(\mathrm{Nm})$ & no & KT & KQ & $\begin{array}{c}10 \\
\text { KQ }\end{array}$ & $\mathrm{T}(\%)$ & $\mathrm{Q}(\%)$ & пo \\
\hline 0.6 & -136.05 & 5.26 & 0.78 & -254.06 & 4.50 & 0.005 & 0.110 & 0.006 & 0.06 & 86.74 & -14.43 & -99.33 \\
\hline 0.8 & -459.83 & 0.45 & 40.83 & -565.68 & 0.34 & 0.204 & 0.244 & 0.0005 & 0.005 & 23.02 & -24.60 & -99.50 \\
\hline 1 & -858.40 & 7.94 & 5.45 & -962.82 & 5.83 & 0.026 & 0.415 & 0.008 & 0.08 & 12.17 & -26.63 & -99.53 \\
\hline 1.2 & $-1,293.41$ & 16.02 & 4.88 & $-1,507.84$ & 14.25 & 0.020 & 0.651 & 0.019 & 0.19 & 16.58 & -11.07 & -99.60 \\
\hline 1.4 & $-1,810.11$ & 25.29 & 5.05 & $-2,143.67$ & 25.12 & 0.018 & 0.925 & 0.034 & 0.34 & 18.43 & -0.65 & -99.64 \\
\hline
\end{tabular}




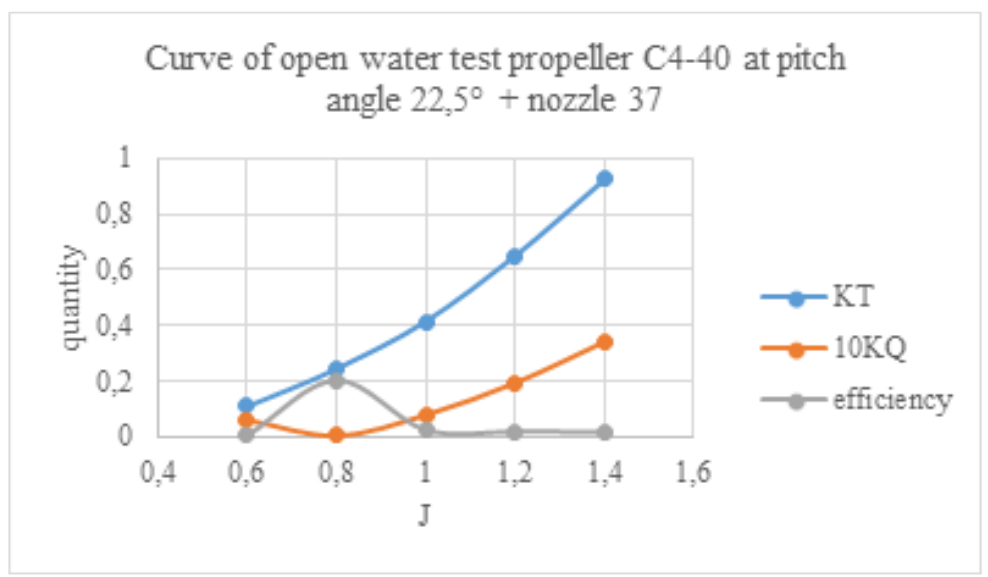

Figure. 9. Curve Open Water Test Propeller C4-40 pitch angle $0^{\circ}$ and nozzle $37^{\circ}$.

The torque value has decreased compared to the simulation without kort nozzle. The biggest decrease was $-26.63 \%$ on the $\mathrm{J} 1$ from $7.94 \mathrm{~N}$ of torque to 5.82 $\mathrm{Nm}$.

For the efficiency value produced by the propeller C4-40 pitch angle $22.5^{\circ}$ with kort nozzle 37 experienced a very decrease significantly. With the average decrease is $99.5 \%$.

3) Analysis of Propeller C4-40 Pitch Angle $45^{\circ}$ with Kort Nozzle 37
From table 6 it can be seen that the addition of kort nozzle 37 on the propeller C4-40 pitch angle $45^{\circ}$ causes the thrust value to decrease very significantly.

The torque value has decreased compared to without the kort nozzle.

For the efficiency value produced by the propeller C4-40 pitch angle $45^{\circ}$ with kort nozzle 37 decrease significantly. With the average decrease is $99 \%$.

TABLE 6.

ANALYSIS OF PROPELLER C4-40 PITCH ANGLE $45^{\circ}$ WITH KORT NOZZLE 37

\begin{tabular}{|c|c|c|c|c|c|c|c|c|c|c|c|c|}
\hline \multirow[b]{2}{*}{$\mathrm{J}$} & \multicolumn{3}{|c|}{$\begin{array}{c}\text { Simulation Result of } \\
\text { Propeller C4-40 at Pitch } \\
\text { Angle } 45^{\circ}\end{array}$} & \multicolumn{6}{|c|}{$\begin{array}{l}\text { Simulation Result of Propeller C4-40 at Pitch Angle } 45^{\circ}+ \\
\text { nozzle } 37\end{array}$} & \multicolumn{3}{|c|}{ increase } \\
\hline & $\mathrm{T}(\mathrm{N})$ & $\begin{array}{c}\mathrm{Q} \\
(\mathrm{Nm}) \\
\end{array}$ & no & $\mathrm{T}(\mathrm{N})$ & $\begin{array}{c}\mathrm{Q} \\
(\mathrm{Nm})\end{array}$ & no & KT & KQ & $10 \mathrm{KQ}$ & $\mathrm{T}(\%)$ & $\mathrm{Q}(\%)$ & пo \\
\hline & $1,124.5$ & & & & & & & & & & & \\
\hline 0.6 & 6 & 75.90 & 0.45 & 602.72 & 50.49 & 0.0011 & 0.26 & 0.07 & 0.69 & -46.40 & -33.49 & -99.75 \\
\hline 0.8 & 903.15 & 64.33 & 0.57 & 404.17 & 38.57 & 0.0013 & 0.17 & 0.05 & 0.53 & -55.25 & -40.03 & -99.77 \\
\hline 1 & 682.09 & 52.63 & 0.65 & 178.95 & 25.34 & 0.0011 & 0.08 & 0.03 & 0.35 & -73.76 & -51.86 & -99.83 \\
\hline 1.2 & 457.13 & 40.19 & 0.69 & -56.27 & 6.78 & 0.0015 & 0.02 & 0.01 & 0.09 & -112.31 & -83.13 & -99.78 \\
\hline 1.4 & 217.58 & 25.70 & 0.60 & 441.92 & 12.05 & 0.0079 & 0.19 & 0.02 & 0.16 & -303.10 & -53.10 & -98.67 \\
\hline
\end{tabular}

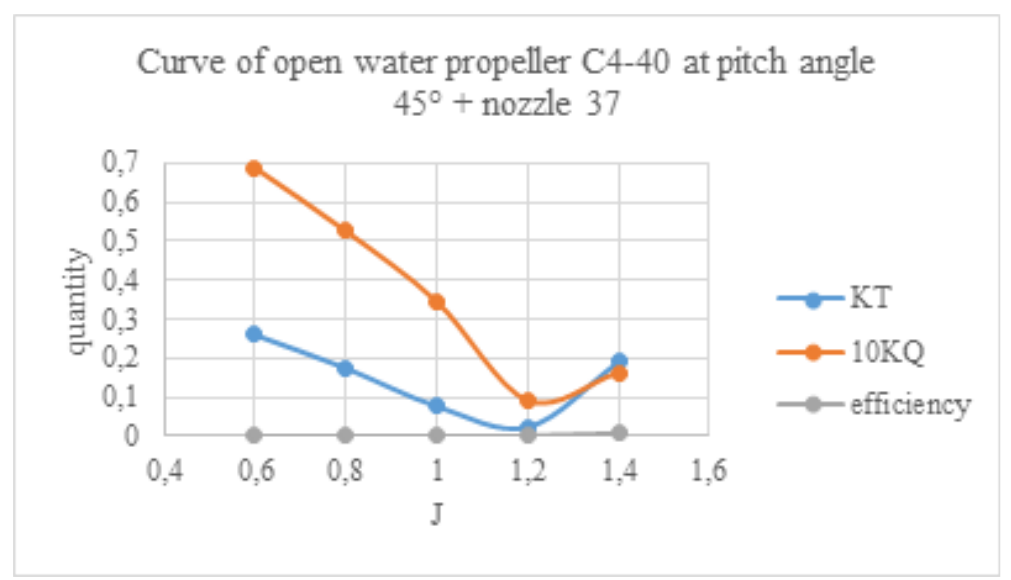

Figure. 10. Curve Open Water Test Propeller C4-40 pitch angle $45^{\circ}$ and nozzle $37^{\circ}$. 
4) Effect of Adding Kort Nozzle 37 on C4-40 Propeller Performance

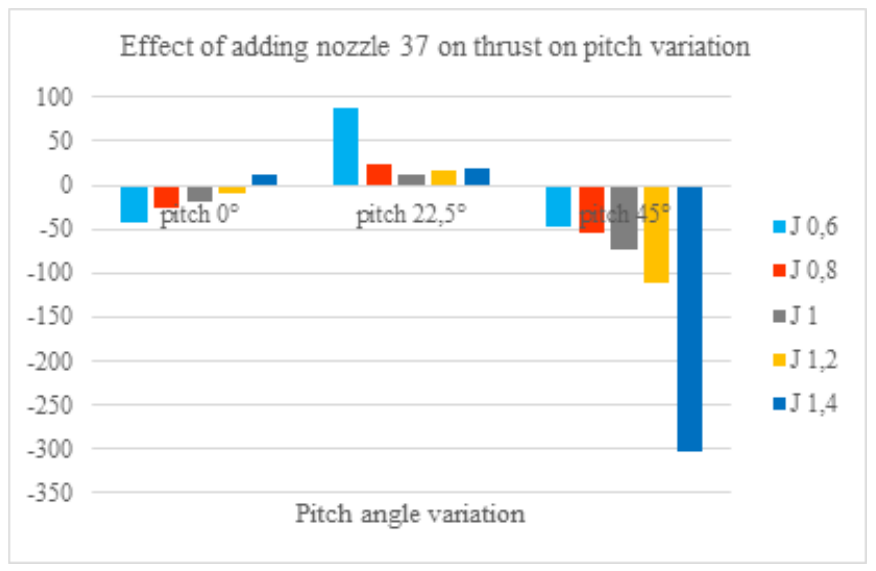

Figure. 11. The effect of adding kort nozzle 37 on thrust on the pitch variation of the propeller C4-40.

From Figure 11 it can be seen that the addition of kort nozzle 37 in each variation of the pitch angle of the propeller C4-40 produces fluctuating thrust. At pitch angle $0^{\circ}$ it increases with every increase in the value of $\mathrm{J}$. At pitch angle $22.5^{\circ}$ it decreases and increases in the form of a curve. And at pitch angle $45^{\circ}$, the thrust value decreases as the $\mathrm{J}$ value increases.
From Figure 12 rom it can be seen that the addition of kort nozzle 37 in each variation of the pitch angle of the propeller $\mathrm{C} 4-40$ produces a fluctuating torque. At pitch angle $0^{\circ}$, the torque value increases with each addition of the $\mathrm{J}$ value. At pitch angle $22.5^{\circ}$, it decreases in all $\mathbf{J}$ values in forms a curve towards the negative. And at a pitch angle $45^{\circ}$, the torque value decreases.

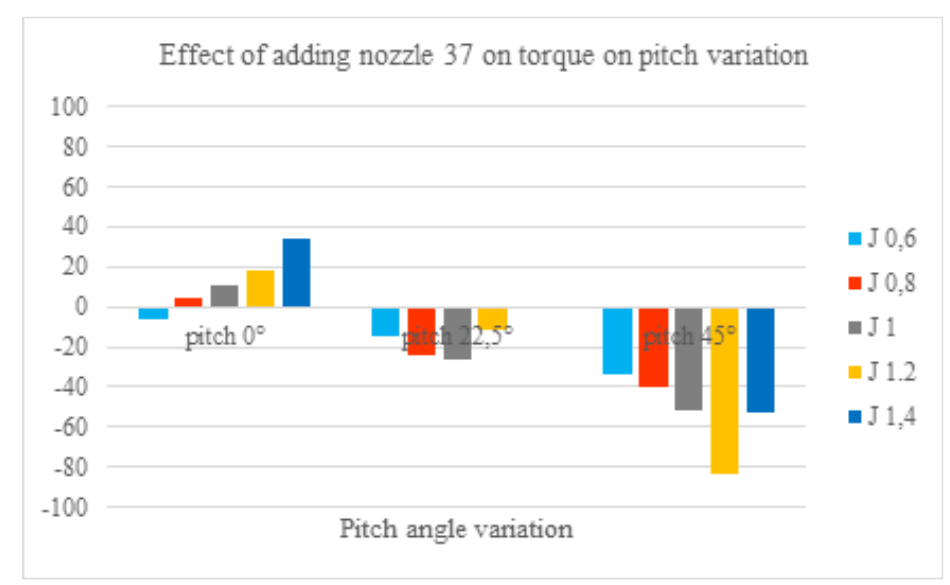

Figure. 12. The effect of adding kort nozzle 37 on torque on the pitch variation of the propeller C4-40.

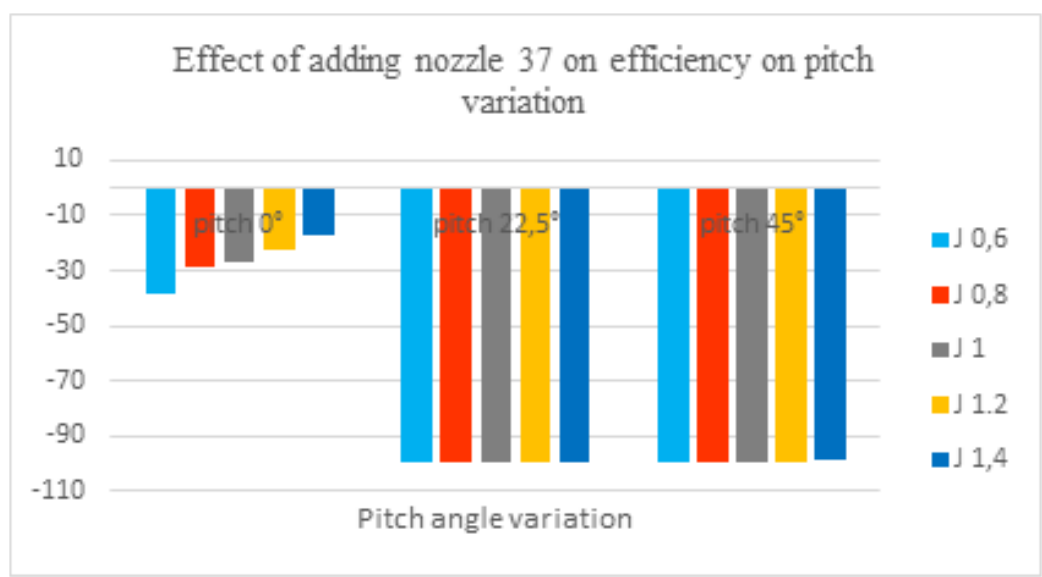

Figure. 13. The effect of adding kort nozzle 37 on efficiency on the pitch variation of the propeller C4-40. 
From Figure 13 it can be seen that the addition of kort nozzle 37 in each variation of the pitch angle of the propeller C4-40 results in a decrease in efficiency. Only at pitch angle $0^{\circ}$ the efficiency value increases with every increase in the value of $\mathrm{J}$, but this value still decreases compared to a propeller without nozzle. From the figure it can be seen that the decrease in the efficiency of the propeller C4-40 at pitch angles $22.5^{\circ}$ and $45^{\circ}$ has almost the same value.

5) Explanation of Negative Thrust Propeller C440 .

NUMECA

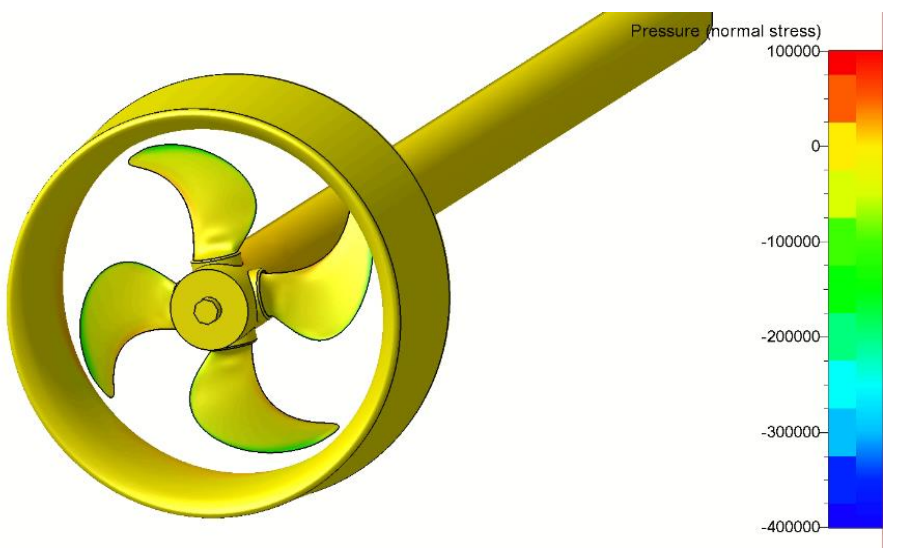

Figure. 14. Pressure face propeller $\mathrm{C} 4-40$ pitch angle $0^{\circ}$ and nozzle 37 at $\mathrm{J} 1$.

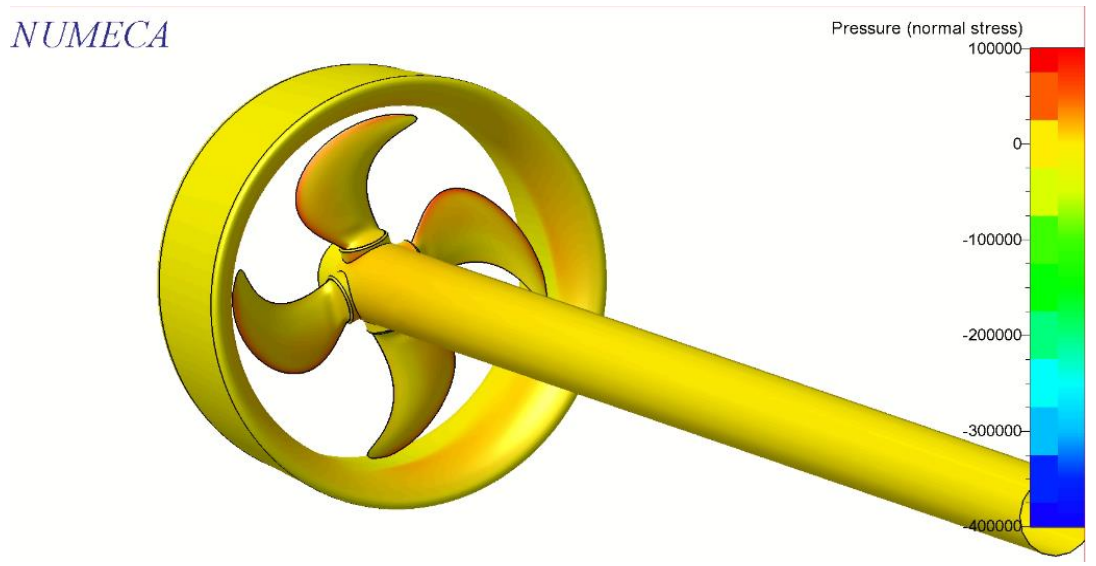

Figure. 15. Pressure back propeller $\mathrm{C} 4-40$ pitch angle $0^{\circ}$ and nozzle kort 37 at $\mathrm{J} 1$.

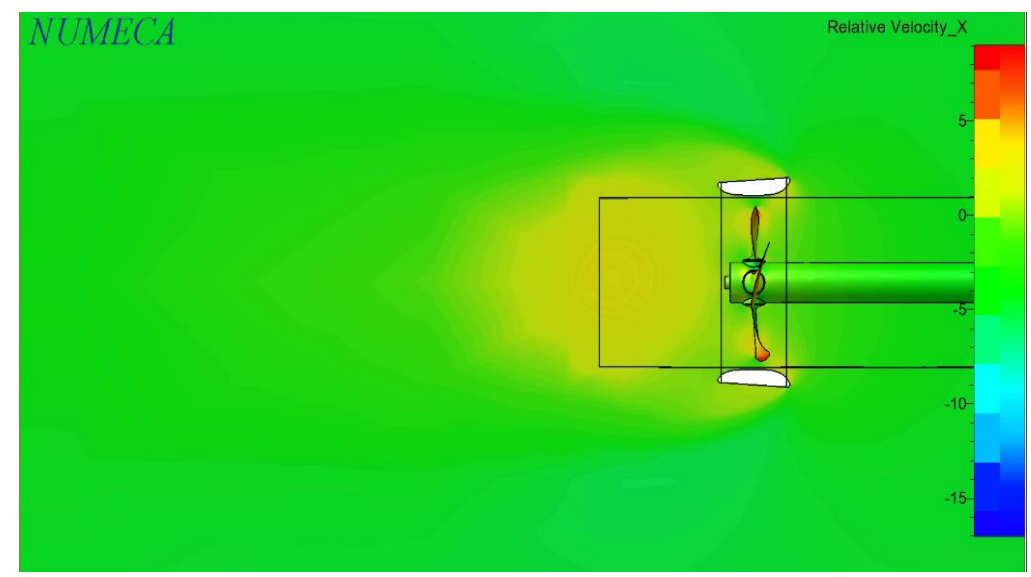

Figure. 16. Velocity propeller $\mathrm{C} 4-40$ pitch angle $0^{\circ}$ and kort nozzle 37 at $\mathrm{J} 1$. 
Referring to table 2, it is known that the thrust value of the propeller $\mathrm{C} 4-40$ at pitch angle $0^{\circ}$, coefficient advance 1 is $-1504,263 \mathrm{~N}$. This negative thrust value can be explained from Figure 15 shows that the back propeller pressure is greater than the face. It is further strengthened from the velocity shown in Figure 16, where the velocity of the water in the back propeller is smaller causing greater pressure than the face. Because the back pressure is greater than the face pressure it can cause the propeller to move backwards

\section{CONCLUSION}

From the research that has been done, the authors can draw the following conclusions:

1. The addition of kort nozzle 37 can significantly change the thrust of the propeller C4-40 at every pitch angle. At pitch $0^{\circ}$, the thrust value decreased except at $\mathrm{J} 1.4$, that increases by $10,99 \%$. The biggest decrease was $42.55 \%$ at $\mathrm{J} 0.6$ from thrust $898.58 \mathrm{~N}$ to $-516.21 \mathrm{~N}$. At pitch $22.5^{\circ}$, the thrust value has increased significantly. The biggest increase was $86.74 \%$ at $\mathrm{J} 0.6$ from $-136.05 \mathrm{~N}$ thrust to $-254.06 \mathrm{~N}$. At pitch $45^{\circ}$, the thrust value has decreased significantly. The biggest decrease is $303.10 \%$ at $\mathrm{J} 0.6$ from thrust $1124.56 \mathrm{~N}$ to 602.72 $\mathrm{N}$.

2. The addition of kort nozzle 37 can significantly change the torque of the propeller C4-40 at every pitch angle. At pitch $0^{\circ}$, the torque increases except for $\mathrm{J} 0.6$, that decreases by $6.46 \%$ from $27.71 \mathrm{Nm}$ to $25.92 \mathrm{Nm}$. The biggest increase was $33.85 \%$ on the J 1.4 from $60.4 \mathrm{Nm}$ of torque to $80.85 \mathrm{Nm}$. At pitch $22.5^{\circ}$, the torque decrease compared to without nozzle. The biggest decrease is $-26.63 \%$ on the $\mathrm{J} 1$ from $7.94 \mathrm{~N}$ of torque to $5.82 \mathrm{Nm}$ At $45^{\circ}$ pitch there is a significant decrease compared to without a nozzle. The biggest decrease was $83.13 \%$ on the J 1.2 from $40.19 \mathrm{Nm}$ of torque to $6.78 \mathrm{Nm}$.

3. The efficiency of the propeller C4-40 decreased after the addition of kort nozzle 37 . At pitch $0^{\circ}$, the biggest decrease at $\mathbf{J} 0.6$ is $38.59 \%$ from efficiency 0.98 to 0.6 . At $22.5^{\circ}$ pitch, the biggest decrease at $\mathrm{J}$ 1.4 is $99.63 \%$ from efficiency 25.29 to 0.018 . At a pitch of $45^{\circ}$, the largest decrease in $\mathrm{J} 1$ is $99.83 \%$ from 0.65 efficiency to 0.0011 .

\section{ACKNOWLEDGEMENTS}

Thank you to all who have helped to complete this research, especially to supervisors and members of the MMD laboratory, ITS.

\section{REFERENCES}

[1] Harvald, Sv.Aa. 1983. Resistance and Propulsion of Ship. A Wiley-Interscience Publication: Denmark.

[2] Putra, Pradika Desto, Andi Trimulyono, Eko Sasmito Hadi. 2015. Analisa Pengaruh Pemasangan Energy Saving Device (ESD) Propeller Boss Cap Fins (PBCF) dan Kort Nozzle pada Propeller Type B-Series dan Propeller Type AU Terhadap Gaya Dorong Propeller dengan Metode CFD. Program Study S1 Teknik Perkapalan. Fakultas Teknik, Universitas DIponegoro
[3] Carlton, J. 2007. Marine Propeller And Propulsion Second Edition. Boston: ELSEVIER

[4] Huda, Nurul. 2013. Analisa pengaruh Energy Saving Device pada Propeller dengan Metode CFD. Tugas Akhir, Jurusan Teknik Perkapalan, UNDIP: Semarang

[5] G. Kuiper. 1992. 'The Wageningen Propeller Series'. MARIN Publication 92-001, published on the occasion of its 60th anniversary, Wageningen, the Netherlands

[6] Elbatran. 2014. Stationary and Low Speed Performance Characteristics of Open and Ducted CPPs. International Marine and Offshore Engineering Conference (IMOC 2014)

[7] Bhattacharyya, Arniban, Vladimir Krasilnikov, Sverre Steen. 2016 Scale effect on open water characteristics of a controllable pitch propeller working within different duct design. Ocean Engineering 112 (2016) 226-242

[8] Carlton, J. 2010. Marine Propeller and Propulsion Second Edition. Selsevier Ltd. USA

[9] Schwer, E. L., 2008. Is Your Mesh Refined Enough? Estimating Discretization Error Using GCI. Bamberg: LS-DYNA Anwenderforum. 